\title{
Seasonality of ecosystem respiration in a double-cropping paddy field in Bangladesh
}

\section{S. Hossen ${ }^{1}$, M. Mano ${ }^{2}$, A. Miyata ${ }^{2}$, M. A. Baten ${ }^{3}$, and T. Hiyama}

${ }^{1}$ Graduate School of Environmental Studies, Nagoya University, Nagoya 464-8601, Japan ${ }^{2}$ National Institute for Agro-Environmental Sciences (NIAES), Tsukuba 305-8604, Japan

${ }^{3}$ Department of Environmental Science, Bangladesh Agricultural University (BAU), Mymensingh-2202, Bangladesh

${ }^{4}$ Research Institute for Humanity and Nature (RIHN), Kyoto 603-8047, Japan

Received: 6 July 2011 - Accepted: 19 August 2011 - Published: 26 August 2011

Correspondence to: M. S. Hossen (hossen11@gmail.com)

Published by Copernicus Publications on behalf of the European Geosciences Union.

\section{Seasonality of ecosystem respiration in a double-cropping}

M. S. Hossen et al.

\section{Title Page}

Abstract Introduction

Conclusions References

Tables Figures

14

Back

Close

\section{Full Screen / Esc}

Printer-friendly Version

Interactive Discussion 


\section{Abstract}

Ecosystem respiration (RE) from cultivated ecosystems is important for understanding the role of these ecosystems in the global carbon balance. To evaluate carbon dynamics in a double-rice cropping paddy field, we conducted long-term measurements 5 at Mymensingh, Bangladesh in 2007 using a tower-based eddy covariance technique. The study objectives were to investigate the diurnal and seasonal variations in RE and to develop and evaluate empirical models for predicting variations in RE using environmental parameters. We found that the diurnal pattern of RE was driven by soil temperature (Ts) whereas the seasonal variation in RE was controlled primarily by Ts (S) water content (SWC) in the magnitude of $\mathrm{CO}_{2}$ release. Both the amount and magnitude of $\mathrm{RE}$ variation were larger in the "Boro" dry-season rice growing period from late winter to mid-summer than in the "Aman" wet-season rice growing period from late summer to early winter. Annually, the ratio of RE to gross primary production (GPP) was 0.67 , indicating a net sink of carbon; the two growing seasons had RE/GPP ratios of 0.58 and 0.52 . A model using Ts, SWC, and aboveground biomass predicted daily RE with $R^{2}$ values of 0.87 and 0.62 for the Boro and Aman seasons, respectively.

\section{Introduction}

Ecosystem respiration (RE) is a key ecosystem process through which carbon is released from plants and soil to the atmosphere in the form of carbon dioxide $\left(\mathrm{CO}_{2}\right)$. $\mathrm{RE}$ is an important component of the global carbon cycle (Schlesinger, 1991; Schimel, 1995; Raich et al., 2002), and understanding RE is crucial for clarifying the carbon balance of terrestrial ecosystems and the globe. Terrestrial ecosystems exchange carbon with the atmosphere through the processes of photosynthesis and RE. Therefore, changes in the amount of RE will also influence the balance of atmospheric $\mathrm{CO}_{2}$ and soil carbon storage. Recent studies have found that respiration shifts can be the
BGD

8, 8693-8721, 2011

\section{Seasonality of ecosystem respiration in a double-cropping}

M. S. Hossen et al.

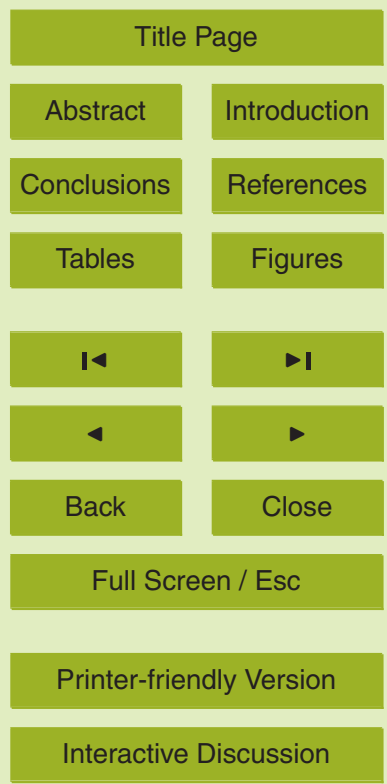


dominant control on interannual variation in the net carbon sink-source status of an ecosystem (Valentini et al., 2000; Saleska et al., 2003; Griffis et al., 2004). Thus, increases in $\mathrm{CO}_{2}$ emissions have the potential to intensify the increasing atmospheric $\mathrm{CO}_{2}$ levels and provide a positive feedback to global warming (Raich and Tufekcioglu, 5 2000).

$R E$ is composed of two distinct processes: autotrophic and heterotrophic respiration. The proportional contributions of autotrophic and heterotrophic respiration can vary diurnally, seasonally, spatially, and also with vegetation type (Hanson et al., 2000). The amount of RE is controlled by complex interactions of several environmental factors, 10 among which temperature and moisture are the most important. In several studies researchers have modeled RE by using soil temperature (Ts) as the main controlling factor (Lloyd and Taylor, 1994; Gifford, 2003; Zhou et al., 2007; Jin et al., 2008) because temperature have direct effects on microbial activity and root respiration (Jassal et al., 2008). The soil water content (SWC) acts as the second most important controlling factor of RE specially in arid and semiarid area, by influencing the temperature sensitivity of soil respiration (Davidson et al., 2006) and also by influencing the plant growth and soil microbes (Qi and Xu, 2001). The terrestrial ecosystem often experiences moisture deficits to some extent, and soil moisture plays a vital role along with soil temperature in regulating $\mathrm{RE}$. In the paddy ecosystem, however, moisture deficits are rare, and instead soil oversaturation may occur. Accordingly, the roles of Ts and SWC are important for evaluating RE of paddy fields. The complexity of the interactions of factors controlling RE has delayed the development of mechanistic models (Farquhar et al., 1980).

Agricultural management practices are known to influence $\mathrm{CO}_{2}$ emissions (IPCC, 25 2007). In natural ecosystems such as grassland and forest, the rate of carbon cycle change is quite slow. On the other hand, in anthropogenic ecosystems such as cropland, the carbon cycle may change rapidly and manipulations of the carbon budget to increase carbon storage in soil and/or reduce the emission of methane and nitrous oxide are possible by changing management and cultivation practices. Cultivation
BGD

8, 8693-8721, 2011

\section{Seasonality of ecosystem respiration in a double-cropping}

M. S. Hossen et al.

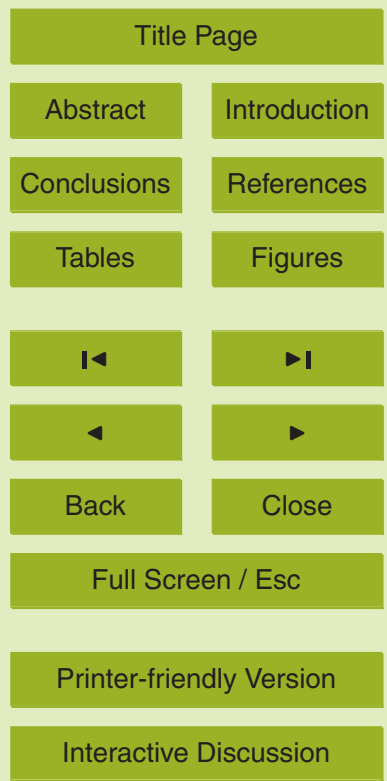


practices differ among and even within countries. Local agricultural management practices may influence the diurnal and seasonal variations in RE from paddy fields. In Bangladesh, rice covers almost $80 \%$ of arable land (Rahman et al., 2001). Rice is cultivated year-round in single-, double-, and even triple-cropping systems. The cultivation 5 of paddy rice differs from that of many other crops. The paddy soils are submerged for much of the growing season, either naturally or artificially, and then remain drained for the rest of the period, again either naturally or artificially. This cyclical change in micro-environmental conditions differentiates paddy soils from the soils in other terrestrial ecosystems. Accordingly, it is important to study how the carbon budget of paddy

10 fields is influenced by water management, which can also be useful for sustainable agricultural production and global warming mitigation.

Many studies have evaluated RE from various ecosystem types worldwide, including grassland and forest ecosystems. However, RE studies of rice paddy fields, especially double-cropped fields are rare. In this study, we investigated the diurnal and seasonal changes in ecosystem respiration in a double-rice cropping paddy field in Bangladesh to reveal the determinants of seasonal variations in $\mathrm{RE}$ and to establish an empirical model to predict RE in double-rice cropping paddy fields.

\section{Methods}

\subsection{Site descriptions}

20 The study flux site $\left(24.73^{\circ} \mathrm{N}, 90.42^{\circ} \mathrm{E}, 18 \mathrm{~m}\right.$ above sea level) is located in a paddy field at Bangladesh Agricultural University Farmland (Hossen et al., 2011). The climate is tropical monsoon-type. Its mean air temperature is $25.4^{\circ} \mathrm{C}$, and annual rainfall is about 2,055 mm (average: 1980-2007; Yatagai et al., 2009). The summer precipitation from June to September is about $80 \%$ of total precipitation. Annually about $1,500 \mathrm{~mm}$ irrigation was provided which is major in dry-season. The surrounding fields are uniform and used for paddy cultivation which provides long uniform fetch more than $500 \mathrm{~m}$ in
BGD

8, 8693-8721, 2011

\section{Seasonality of ecosystem respiration in a double-cropping}

M. S. Hossen et al.

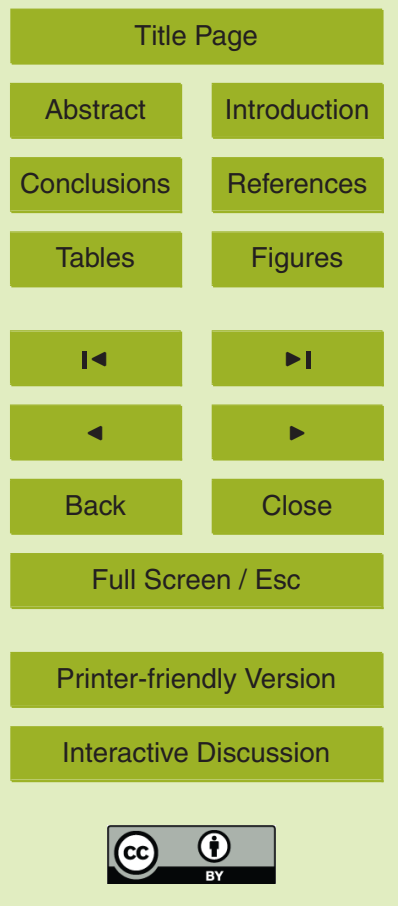


the dominant wind direction with unstable condition. The topography of the area is flat and the soil is dark gray non-calcareous floodplain (UNDP and FAO, 1988) with a sandy loam texture. The site followed double-rice cropping pattern i.e. rice-fallow-rice, with two rice crops per year. The growing season of Boro (dry-season rice) is from 5 late winter (February) to mid-summer (May) while Aman (wet-season rice) is from late summer (August) to early winter (December). The cultivation and field management is shown in Table 1.

\subsection{Eddy covariance measurement}

Measurement in this flux study site was started from February 2006. The $\mathrm{CO}_{2}$ and water vapor fluxes were continuously measured with an open-path eddy covariance system which was consisted of a fast response three-dimensional sonic anemometer (HS; Gill Instruments Ltd., Lymington, UK), and an open-path infrared gas analyzer (IRGA) (LI 7500; LI-COR, Lincoln, NE, USA). The data were recorded with a data logger (CR1000; Campbell Scientific, Logan, UT, USA) at a frequency of $10 \mathrm{~Hz}$. The 15 sensor heads of the sonic anemometer and the IRGA were mounted at a height of $2.9 \mathrm{~m}$ above the ground, with a horizontal distance of $0.16 \mathrm{~m}$ between the two sensor heads. The calibrations of the IRGA to $\mathrm{CO}_{2}$ and $\mathrm{H}_{2} \mathrm{O}$ were made once a year before the Boro rice season by using zero gas (pure air, $\mathrm{CO}_{2}<0.1 \mathrm{ppm}$; Taiyo Nippon Sanso Co., Tokyo, Japan), span gas of $\mathrm{CO}_{2}$ (302.5 ppm $\mathrm{CO}_{2}$ and $503.4 \mathrm{ppm} \mathrm{CO}_{2}$ in

Air, Takachiho Chemical Industrial Co. Ltd., Tokyo, Japan) and dew point generator (LI-610, LI-COR, Lincoln, NE, USA). Results of the calibrations indicated that changes in sensitivities for $\mathrm{CO}_{2}$ and $\mathrm{H}_{2} \mathrm{O}$ were $<1 \%$ and $2.2 \%$, respectively, and offset errors were $<0.1 \mathrm{mmol} \mathrm{m}^{-3}$ and $15 \mathrm{mmol} \mathrm{m}^{-3}$, respectively. Before calculating the half-hourly covariance between vertical wind velocity and scalar quantities, the wind velocity components were rotated based on a double-rotation scheme (Tanner and Thurtell, 1969; Kaimal and Finnigan, 1994). Frequency losses due to path-length averaging and the separation between the anemometer and the IRGA were corrected according to the procedure proposed by Massman (2000). $\mathrm{CO}_{2}$ and water vapor fluxes were corrected 8697
BGD

8, 8693-8721, 2011

\section{Seasonality of ecosystem respiration in a double-cropping}

M. S. Hossen et al.

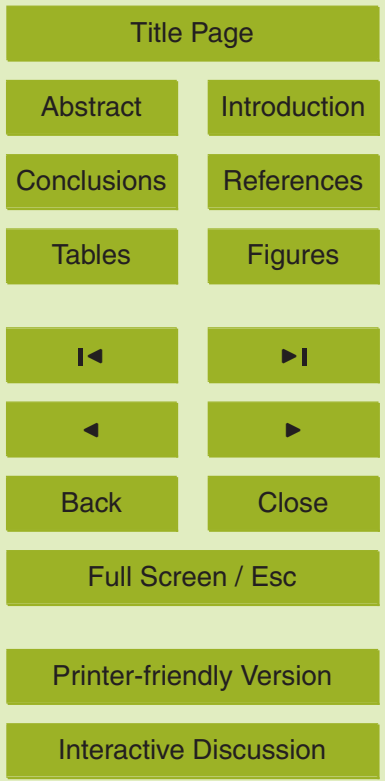

Interactive Discussion 
for concurrent density fluctuation (Webb et al., 1980). Storage of $\mathrm{CO}_{2}$ in the layer below the eddy covariance sensors was estimated from the temporal change in the mean $\mathrm{CO}_{2}$ concentration at the eddy covariance measurement height $(2.9 \mathrm{~m})$ and added to the turbulent flux to obtain the net ecosystem $\mathrm{CO}_{2}$ exchange (NEE). Energy balance 5 of this study site was 0.75 (Hossen at al., 2011), which is reasonable in the range reported by most flux sites (Wilson et al., 2002). $\mathrm{CO}_{2}$ flux was not corrected for energy balance underestimation in this study although energy balance correction has reported by some researchers (Twine et al., 2000).

\subsection{Micrometeorological and miscellaneous measurements}

10 Additional corresponding micrometeorological measurement also carried continuously with another $3 \mathrm{~m}$ mast. Downward and upward short and long wave radiation and net radiation were measured at a height of $2.9 \mathrm{~m}$ above the ground using a four-component net radiometer (MR40; EKO, Tokyo, Japan). Air temperature and relative humidity were measured at two heights, $1.65 \mathrm{~m}$ and $2.95 \mathrm{~m}$ above the ground using temperature15 humidity sensors (HMP45A; Vaisala Inc., Helsinki, Finland). Home-made T-type thermocouples $(0.25 \mathrm{~mm}$ in diameter) were used to measure soil temperature at depths of $0.045,0.075,0.125$, and $0.225 \mathrm{~m}$ below the ground, and water temperature near the ground and at $0.025 \mathrm{~m}$ above the ground. Soil heat flux was measured using three soil heat flux plates (MF180M; EKO, Tokyo, Japan) placed at a depth of $0.05 \mathrm{~m}$ in the 20 ground. Floodwater depth was measured at two points around the mast using capacitive sensor (6521J; Unidata Pty Ltd., O'Connor, WA, Australia). Incident photosynthetically active radiation (PAR) was measured with quantum sensor (LI190, LICOR, Lincoln, NE, USA) at $2.95 \mathrm{~m}$ above the ground. The volumetric soil water content (SWC) of three soil layers $(0-5 \mathrm{~cm}, 0-10 \mathrm{~cm}, 0-20 \mathrm{~cm})$ was measured with time-domain re-

25 flectometry (TDR) (TDR100; Campbell Scientific, Logan, UT, USA). These supported data of the micrometeorological were sampled every $10 \mathrm{~s}$ and averaged over $30 \mathrm{~min}$ using a data logger (CR23X; Campbell Scientific). The TDR data were sampled every $5 \mathrm{~s}$ and averaged over $30 \mathrm{~min}$ using another data logger (CR10X; Campbell Scientific,
BGD

8, 8693-8721, 2011

\section{Seasonality of ecosystem respiration in a double-cropping}

M. S. Hossen et al.

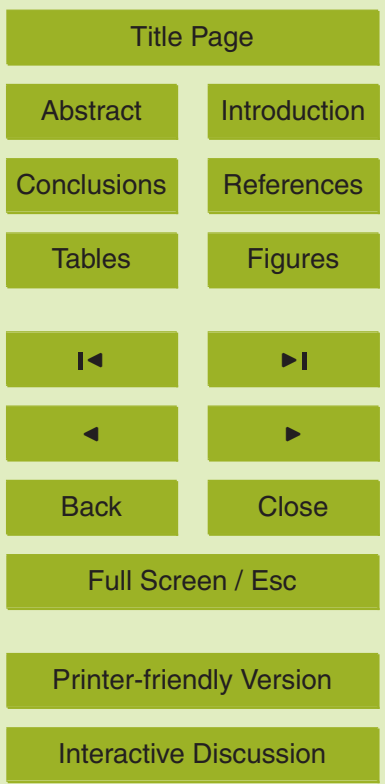


Logan, UT, USA). Daily (24h starting from 06:00) precipitation data were collected from a nearby weather station, which was located $250 \mathrm{~m}$ from the measurement mast. Biological parameter like leaf area index ( $\mathrm{LAl}$ ) and biomass of rice were estimated by destructive method. From one meter areas 3 samples were taken at 10-day intervals 5 during the growing season until just prior to harvest. For each sample, ten stumps of rice were taken and washed in water to remove mud from their roots. The stumps were then separated into stems, roots, leaves and panicles. The separated samples were dried in an oven at $80^{\circ} \mathrm{C}$ for $48 \mathrm{~h}$. Before drying, LAl was calculated from the leaf area of green leaves measured using an automatic leaf area meter (LI 3100; LI-COR, Lin10 coln, NE, USA). For further analysis daily crop biomass was linearly interpolated from 10-days interval data.

\subsection{Quality control and gap filling of flux data and partitioning of NEE}

During long-term measurement, eddy covariance flux data became erroneous for various reasons, such as instrument malfunction, inappropriate atmospheric conditions, rainfall or human disturbance, etc. As quality control tests to eliminate erroneous flux data, we applied the raw data tests proposed by Vickers and Mahrt (1997) to raw timeseries data sampled at $10 \mathrm{~Hz}$, and the sampling error test (Finkelstein and Sims, 2001) to half-hourly fluxes. By applying these tests, $19.7 \%$ of half-hourly sensible heat fluxes, $33.3 \%$ of half-hourly latent heat fluxes and $42.4 \%$ of half-hourly NEE were discarded.

20 To derive continuous time series of half-hourly data of sensible heat flux, latent heat flux and NEE, gap filling was done by using an eddy covariance data processing tool employed by CarboEurope (http://www.bgc-jena.mpg.de/bgc-mdi/html/eddyproc/, Reichstein et al., 2005), which is an improved version of look-up table method (Falge et al., $2001 \mathrm{a}, \mathrm{b}$ ) and considers both the co-variation of fluxes with meteorological variables and the temporal auto-correlation of the fluxes. To reduce uncertainties originating from meteorological data used for the gap-filling, all of the gaps in half-hourly meteorological data (incoming solar radiation, air temperature and water vapor deficit, VPD) were filled before applying the tool. Short-term gaps $(<3 \mathrm{~h})$ in the meteorological data were filled

BGD

8, 8693-8721, 2011

\section{Seasonality of ecosystem respiration in a double-cropping}

M. S. Hossen et al.

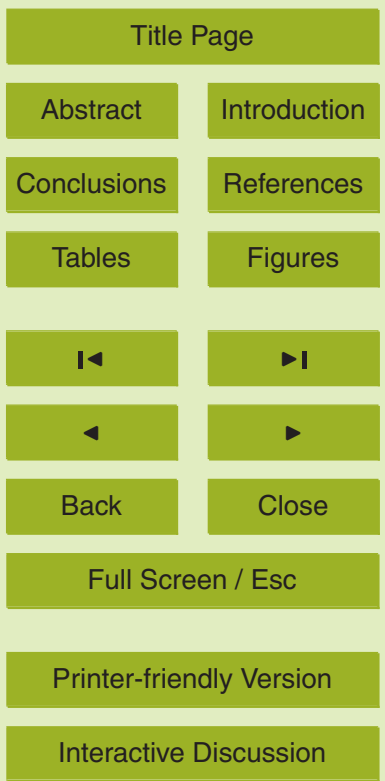


by linear interpolation, while longer gaps were filled by using the mean diurnal course (Falge et al., 2001a) with a 15-day fixed window. The fraction of half-hourly meteorological data filled by the mean diurnal course was $0.3 \%$ for incoming solar radiation and $0.6 \%$ for air temperature and VPD. At our study site, abrupt changes of vegetation 5 by transplanting and harvest of rice could affect the fluxes. To prevent unrealistic gapfilling across these abrupt changes, we applied the tool after separating the whole year dataset into five vegetation periods: (1) the winter fallow period before transplanting of Boro rice, (2) the Boro rice period, (3) the summer fallow period, (4) the Aman rice period and (5) the winter fallow period after harvest of Aman rice. Data selection based 10 on a threshold value of friction velocity was not applied.

After all of the gaps in half-hourly fluxes were filled, partitioning of NEE into gross primary production (GPP) and ecosystem respiration (RE) was done by using the following method: Nighttime half-hourly NEE data (defined as the incoming solar radiation was $<20 \mathrm{~W} \mathrm{~m}^{-2}$ ) in consequent 10 days were selected and the Lloyd-and-Taylor (1994) 15 model of RE as a function of temperature was fitted to our dataset.

$\operatorname{RE}(T)=R_{e_{\text {Tref }}} \exp \left[E_{0}\left(\frac{1}{T_{\text {ref }}-T_{0}}-\frac{1}{T-T_{0}}\right)\right]$,

where RE is the $\mathrm{CO}_{2}$ flux density caused by ecosystem respiration $T_{0}$ and $T_{\text {ref }}$ are constant parameters set at $227.13 \mathrm{~K}$ and $283.15 \mathrm{~K}$, respectively, as Lloyd and Taylor (1994). $E_{0}(\mathrm{~K})$ is a parameter expressing temperature sensitivity of ecosystem respira20 tion, and is determined by the regression but finally set constant throughout the year. $R_{e_{\text {Tref }}}$ is ecosystem respiration at $T_{\text {ref }}$ to be determined every 4 days by the regression after the value of $E_{0}$ is fixed. After RE was estimated for every half-hour using Eq. (1) and the determined parameters $\left(E_{0}\right.$ and $\left.R_{e_{\text {Tref }}}\right)$, GPP was calculated as the difference between estimated RE and gap-filled NEE. In this study, we focus only on RE.
BGD

8, 8693-8721, 2011

\section{Seasonality of ecosystem respiration in a double-cropping}

M. S. Hossen et al.

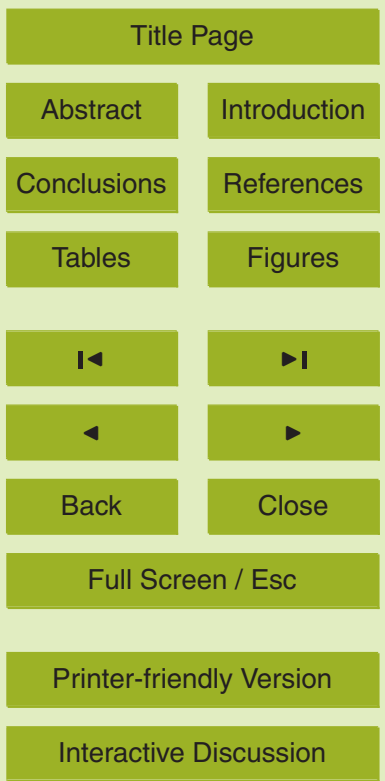




\subsection{Modeling of seasonal variation of ecosystem respiration during the growing season}

In general, short-term variations in RE is strongly influenced by air and/or soil temperature, and as is clear in Eq. (1), the partitioning of NEE applied in this study is also established on the basis of such general modeling. However, when we discuss seasonal variation of RE in croplands, we have to consider seasonal change in crop biomass, which also affects seasonal variation of RE. In terrestrial ecosystem in temperate or cold regions, it is common that seasonal trend of plant biomass is almost in parallel with that of temperature. Influences of these two factors on RE overlap each other, and are sometimes combined into one factor showing temperature sensitivity of $\mathrm{RE}$. As shown later, in our study site during the dry rice (Boro rice) season, the seasonal trend of the crop biomass was similar to that of temperature, while during the wet rice (Aman rice) season, the crop biomass and temperature showed opposite seasonal trends each other. In the latter case, it is critical to model influence of the crop biomass and temperature separately. In addition, it is well known that flooding and drainage of floodwater affect $\mathrm{CO}_{2}$ exchange in paddy fields (e.g. Miyata et al., 2000). Taking all of these effects into account, we made a simple model using soil temperature and SWC in the upper soil layer and aboveground crop biomass to simulate seasonal variation of $\mathrm{RE}$ in the study site:

20

$\operatorname{RE}\left(T_{\mathrm{s}}, \theta, W_{\mathrm{ag}}\right)=R_{0} \exp \left(a T_{\mathrm{s}}\right) f(\theta)$

$R_{0}=b_{1} W_{\mathrm{ag}}+b_{2}$

$f(\theta)=\left\{\begin{array}{cc}c & \left(\theta \leq \theta_{1}\right) \\ c-(c-1)\left(\theta-\theta_{1}\right) & \left(\theta_{1}<\theta \leq \theta_{2}\right) \\ 1 & \left(\theta_{2}<\theta\right)\end{array}\right.$

where $T_{\mathrm{s}}$ represents the soil temperature at $5 \mathrm{~cm}\left({ }^{\circ} \mathrm{C}\right), \theta$ is SWC measured at $0-0.10 \mathrm{~m}$ $\left(\mathrm{m}^{3} \mathrm{~m}^{-3}\right), W_{\mathrm{ag}}$ is aboveground biomass $\left(\mathrm{kg} \mathrm{m}^{-2}\right) \cdot \theta_{1}$ and $\theta_{2}$ are parameters to express 8701
BGD

8, 8693-8721, 2011

Seasonality of ecosystem respiration in a double-cropping

M. S. Hossen et al.

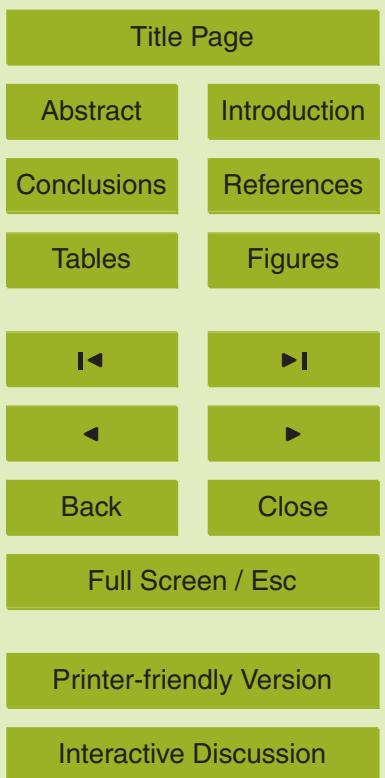

Interactive Discussion 
dependence of RE on SWC, and $a, b_{1}, b_{2}$ and $c(>1)$ are empirical coefficients determined by the regression. In this study, daily values of RE, $T_{s}, \theta$ and $W_{\text {ag }}$ were applied to Eqs. (2, 3 and 4) to determine empirical coefficients of $a, b_{1}, b_{2}$ and $c$. While we set $\theta_{1}$ at $0.46 \mathrm{~m}^{3} \mathrm{~m}^{-3}$ and $\theta_{2}$ at $0.50 \mathrm{~m}^{3} \mathrm{~m}^{-3}$ based on the observation data shown in 5 Fig. 6.

\section{Results and discussion}

\subsection{Environmental and field conditions}

Figure 1 presents the seasonal variations in key meteorological variables in 2007 . The daily mean air temperature at $2.95 \mathrm{~m}$ height followed a typical seasonal pattern for the 10 Northern Hemisphere, with a maximum of $32^{\circ} \mathrm{C}$ in August (day of year, DOY, 222), minimum of $13^{\circ} \mathrm{C}$ in January (DOY 15), and an annual mean of $24^{\circ} \mathrm{C}$. The daily mean soil temperature (Ts) at $0.045 \mathrm{~m}$ depth showed similar seasonal variation to the daily mean air temperature (Ta). Because the soil surface was mostly covered by water provided by irrigation and rainfall, the volumetric SWC at $0-0.10 \mathrm{~m}$ depth generally remained 15 high at around $0.5 \mathrm{~m}^{3} \mathrm{~m}^{-3}$, except during a drained period prior to the harvest of Boro rice, the mid- and late growing season of rain-fed Aman rice, and a drained fallow period after the harvest of Aman rice. The SWC during the summer fallow period after the harvest of Boro rice (DOY 141-230) remained $>0.5 \mathrm{~m}^{3} \mathrm{~m}^{-3}$ due to ample summer precipitation. The annual mean daily solar radiation in 2007 was $15.1 \mathrm{MJ} \mathrm{m}^{-2} \mathrm{~d}^{-1}$ with a maximum of $28.0 \mathrm{MJ} \mathrm{m}^{-2} \mathrm{~d}^{-1}$ (DOY 217). The annual precipitation in 2007 was $2,763 \mathrm{~mm}, 80 \%$ of which was observed from mid-May to mid-September. The seasonal variation in daily sum of latent heat flux (LE) followed the seasonal trend in Rs with a maximum of $16.1 \mathrm{MJ} \mathrm{m}^{-2} \mathrm{~d}^{-1}$ (DOY 264) whereas the seasonal change in daily sum of sensible heat flux $(\mathrm{H})$ was small.

The LAl of rice reached the maximum of $5.9 \pm 1.3 \mathrm{~m}^{2} \mathrm{~m}^{-2}$ (the mean \pm the standard deviation) at DOY 104 (75 days after transplanting for Boro rice), and $4.6 \pm 1.0 \mathrm{~m}^{2} \mathrm{~m}^{-2}$ at DOY 296 (64 days after transplanting for Aman rice), respectively (Fig. 2a). The total

\section{Seasonality of ecosystem respiration in a double-cropping}

M. S. Hossen et al.

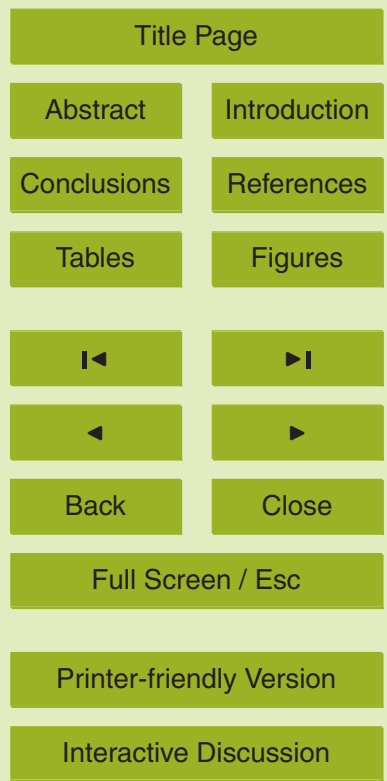


crop biomass increased gradually and at harvest it was $\left(1.89 \pm 0.21 \mathrm{~kg} \mathrm{~m}^{-2}\right)$ in the Boro rice and $\left(1.61 \pm 0.28 \mathrm{~kg} \mathrm{~m}^{-2}\right)$ in the Aman rice (Fig. $\left.2 b\right)$. Larger LAl and crop biomass in the Boro rice season than in the Aman rice season was common in this study area. This is due to the difference in cultivar type between the two growing seasons.

\section{$5 \quad 3.2$ Diurnal variation in ecosystem respiration}

The mean diurnal variations in RE, Ts, and SWC are presented in Fig. 3. In this figure, the growing period was separated into four distinct phenological growth stages: vegetative, reproductive, mature, and the subsequent ratoon or fallow period. In each period, RE showed distinct diurnal variation: $\mathrm{CO}_{2}$ efflux started to increase in the morning, 10 reached a peak from noon to mid-afternoon (12:00-14:00), and then declined in the late afternoon and throughout the night. The mean and the amplitude of the diurnal variation in RE differed between phenological growth stages. The amplitude increased with rice growth during both growing seasons. The diurnal variations in Ts were similar to those for RE, indicating the close relationship between RE and Ts in diurnal cycles. Note that during the Boro season, the mean diurnal variation in RE increased with rice growth, whereas the opposite trend occurred during the Aman season. These contrasting seasonal trends in RE were also observed with Ts, as discussed further in the next section. The SWC did not show diurnal variation in any phenological growth stage. The lower SWC recorded during the vegetative period in both growing seasons and in the fallow period after the Aman season was due to drained days included in the respective periods.

\subsection{Seasonal variations in ecosystem respiration}

Seasonal variation in RE has been observed in almost all ecosystems, but the seasonality and the magnitude of variation depend on the ecosystem type and climate (Grogan and Chapin, 1999). As shown in Fig. 4, the study site showed clear seasonal variation in daily $R E$. The seasonal variation in daily $R E$ in the double-rice cropping field was characterized by two peaks annually: one in the late Boro season (mid-May) 8703
BGD

8, 8693-8721, 2011

\section{Seasonality of ecosystem respiration in a double-cropping}

M. S. Hossen et al.

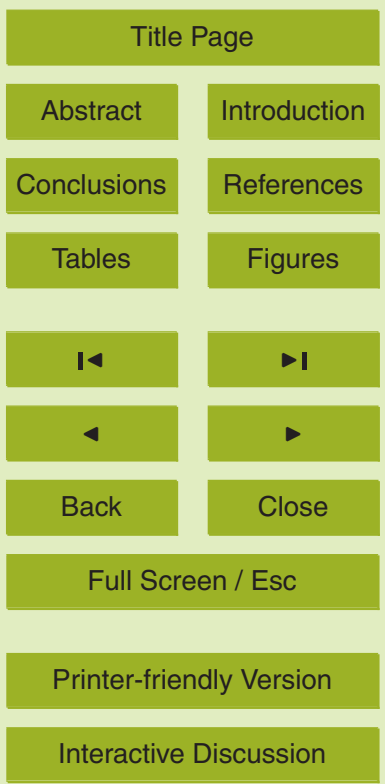


and another in the mid-Aman season (late September). The peak in the Boro season was larger. On the basis of growing status, RE over the entire year could be divided into four periods: two growing seasons (Boro and Aman), a flooded fallow period in summer, and a drained fallow period in winter. RE during the two growing seasons 5 showed opposite seasonal patterns. In the Boro season, RE increased gradually with rice growth, reaching a seasonal maximum around the time of harvest in mid-May. In contrast, in the Aman season, RE increased rapidly in the early growth stage to the seasonal peak in late September, and then decreased gradually.

During the summer fallow period considerable large RE was observed caused by 10 respiration of the ratoon re-growth. $\mathrm{RE}$ during the summer fallow period was almost balanced by active photosynthetic $\mathrm{CO}_{2}$ assimilation, and the resultant net $\mathrm{CO}_{2}$ exchange (NEE) ranged mostly between -1.5 and $1.5 \mathrm{~g} \mathrm{C} \mathrm{m}^{-2} \mathrm{~d}^{-1}$ (data not shown). Although the soil temperature was high $\left(>25^{\circ} \mathrm{C}\right.$ ) and fresh organic matter (mainly roots of the primary crop) was supplied into the soil after the Boro rice harvest, the contribution of $\mathrm{CO}_{2}$ 15 respired from soil to RE was small because the field was still covered by standing water. Water coverage of the field during the summer fallow period was caused by excessive precipitation and poor drainage, which is common in paddy fields in Bangladesh. Flooded conditions in the summer fallow period suppressed RE. This situation differs from that in rice fields in central Japan, where larger RE per unit aboveground biomass 20 has been found in the drained ratoon crop period than in the main crop period (Saito et al., 2005). RE decreased after the field was partially ploughed in late July. It was due to tillage alter microbial parameters and labile organic matter and also standing water inhibit diffusion of soil microbial respiration. The short-term changes in $\mathrm{CO}_{2}$ flux from soils after plowing are known to be important, as in Reicosky and Lindstrom (1993), 25 in which the $\mathrm{CO}_{2}$ flux decreased from a maximum of 114 to $48 \mathrm{~g} \mathrm{CO}_{2} \mathrm{~m}^{-2} \mathrm{~h}^{-1}$ within a lapse of $8 \mathrm{~min}$ and down to $8 \mathrm{~g} \mathrm{CO}_{2} \mathrm{~m}^{-2} \mathrm{~h}^{-1}$ at $3.5 \mathrm{~h}$. Furthermore, RE was found to be smaller in the winter fallow period than in the summer fallow period due to lower soil temperatures and dry conditions unfavorable for ratoon re-growth.

\section{BGD}

8, 8693-8721, 2011

\section{Seasonality of ecosystem respiration in a double-cropping}

M. S. Hossen et al.

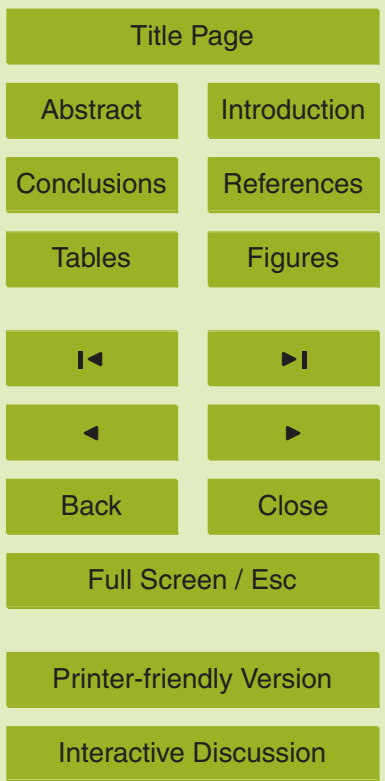


The seasonal averages of daily $R E$ in each period are given in Table 2 . The difference between the Boro $\left(3.76 \mathrm{~g} \mathrm{C} \mathrm{m}^{-2} \mathrm{~d}^{-1}\right)$ and Aman $\left(3.08 \mathrm{~g} \mathrm{C} \mathrm{m}^{-2} \mathrm{~d}^{-1}\right)$ seasons was due to larger crop biomass (Figure $2 \mathrm{~b}$ ) and longer drained days in the Boro growing season (Table 1). Although the magnitude was different, the seasonality of RE during the Boro 5 rice season was similar to that observed in previous season-long studies in paddy fields in other areas, such as in the US state of Texas (Campbell et al., 2001), central Japan (Saito et al., 2005), and the Philippines (Alberto et al., 2009). The different magnitudes in $R E$ in most of these sites might be due to differences in cultivar type, climate, soil and management practices. RE in our study site was less than that reported for the

USA, Japan, and Philippines. The seasonality of RE during Boro season found similar pattern but during the Aman growing season displayed a pattern different from other sites. The ratio of RE to GPP in our study site ( 0.58 for Boro and 0.52 for Aman growing seasons) was the lowest among the sites reported above: 0.65 in Japan (Saito et al 2005), and 0.67 and 0.83 in flooded and aerobic rice fields in the Philippines (Alberto 15 et al., 2009). The annual RE/GPP at our site was 0.67 (Table 2).

\subsection{Factor affecting ecosystem respiration}

As shown in Fig. 5, daily RE per unit aboveground biomass (RE, B) was larger and had a higher magnitude in the first drained subperiods for both the Boro and Aman seasons than in the other subperiods. However, the data were too scattered to find any relationship between RE, $B$ and Ts. This was mainly due to the small biomass. Except for the first drained period, RE, B showed an exponential increase with Ts (Fig. 5). RE, $B$ in the first drained subperiods was about 3- to 4-fold greater than that in the second drained subperiods because the removal of standing water enhanced the direct $\mathrm{CO}_{2}$ diffusion from the soil during low biomass periods. In contrast, RE, B in the second 25 drained periods did not show large differences from the preceding flooded subperiods. This indicates that ecosystem respiration in the late growing period was dominated by respiration from sufficiently large aboveground biomass, and it was therefore less

\section{5}

\section{BGD}

8, 8693-8721, 2011

\section{Seasonality of ecosystem respiration in a double-cropping}

M. S. Hossen et al.

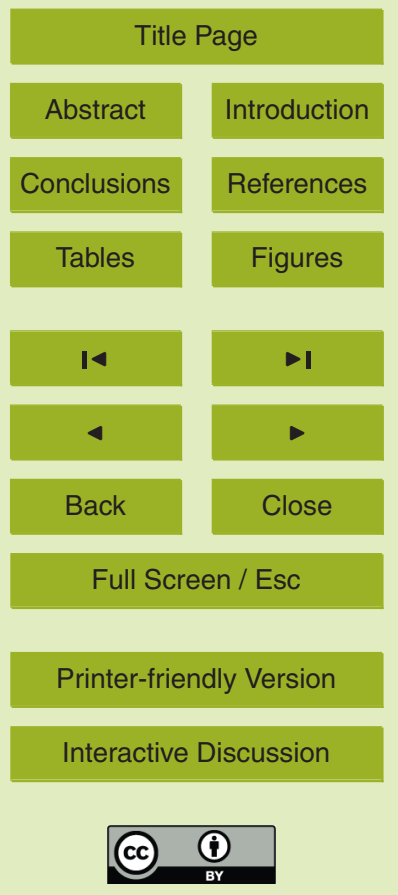


influenced by soil respiration. The soil water content also showed impacts on ecosystem respiration in both the Boro and Aman seasons, as depicted in Fig. 6. Within similar temperature and crop biomass change, the change in RE was also influenced by SWC, and higher RE was observed with lower SWC conditions for both growing 5 seasons. For both Boro and Aman rice season it was found that after $0.46 \mathrm{~m}^{3} \mathrm{~m}^{-3} \mathrm{RE}$ showed decreasing trend with increasing SWC. Therefore we selected $0.46 \mathrm{~m}^{3} \mathrm{~m}^{-3}$ as a threshold value of SWC in our proposed model (Eq. 4).

\subsection{Modeling ecosystem respiration}

Double-cropping-field models are usually based on each crop period and fallow period. 10 We applied our model to four distinctive periods. The data in Figs. 5 and 6 demonstrated that RE of the paddy field was controlled by Ts, SWC, and AGB; therefore, we developed our model based on those parameters. Table 3 provides the fitted relationship of daily ecosystem respiration with environmental factors. The model provided better fits during the Boro growing period than the Aman growing period, accounting for $87 \%$ and $62 \%$ of the variation in ecosystem respiration, respectively (Fig. 7 ). The early drained periods showed relatively higher magnitudes of RE instead of lower biomass (Fig. 5). It is reported by Lei and Yang (2010) that using long term (seasonal) $Q_{10}$ influenced RE during early stage and mature stage therefore short term $Q_{10}$ is better for RE modeling for crop. During the Aman growing season, the early drained period was also a higher temperature period, whereas the temperature was lower during the higher biomass stage. For this reason estimated RE during Aman season showed moderate. On the other hand, during Boro season any kind of model like even linear or exponential model using only Ts showed good result.

Rapid variation in crop phenology was observed in the paddy field, and ecosystem respiration was evaluated by the model based on the growing periods and non-growing periods of single-cropping patterns. The rate of soil respiration under favorable temperature and moisture conditions is generally limited by the supply of soil organic matter
BGD

8, 8693-8721, 2011

\section{Seasonality of ecosystem respiration in a double-cropping}

M. S. Hossen et al.

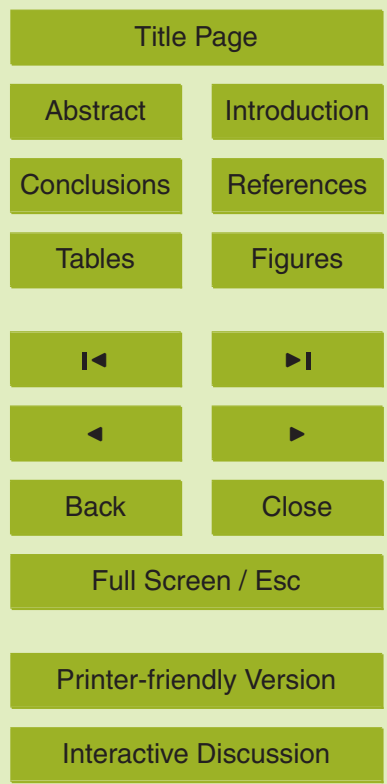


(SOM). Agricultural practices that increase SOM usually enhance heterotrophic respiration. Therefore, further studies should include SOM data and consider the impacts of other environmental factors.

\section{Conclusions}

5 In a double-rice cropping paddy field in Bangladesh, a distinct pattern of ecosystem respiration was observed. Boro rice cultivated from late winter to mid-summer released higher RE both in amount and magnitude than Aman rice cultivated from late summer to early winter. The seasonality of RE in Boro rice was similar to that reported in other parts of the world, while that in Aman rice was different. The diurnal variations in soil 10 temperature revealed a very close relation with $\mathrm{RE}$, whereas soil moisture showed no role. On the contrary, seasonal variations in RE were controlled primarily by soil temperature, soil moisture, and aboveground crop biomass. For both growing seasons, higher magnitudes of RE were observed during the drained and higher temperature periods. The ratio of RE to GPP was 0.58 for the Boro season, 0.52 for Aman season, 15 and 0.67 for the entire year. The model of soil temperature, soil moisture, and aboveground biomass showed better performance for predicting the daily $\mathrm{RE}$, with $R^{2}$ values of 0.87 and 0.62 for the Boro and Aman seasons, respectively.

Acknowledgements. The first author was supported by the Japanese Ministry of Education, Culture, Sports, Science and Technology (MEXT) Scholarship Program. The study site was 20 financially supported by the JSPS-UGC Bilateral Coordination Fund (FY2005-2006) and Science and Technology Promotion Research Fund (FY2005-2007), MEXT, Japan and Global Environment Research Account for National Institutes, MoE, Japan. We are grateful to Dr Y. Ohtani, the then-chair of AsiaFlux, for assistance with the research funding. We also thank Bangladesh Agricultural University (BAU) and the Bangladesh Agricultural University Research

25 System (BAURES) for their cooperation with the project. Special thanks are extended to M. Huq, R. Khatun, B. Khan, G. H. Han, and K. Ono for their efforts to establish the foundation and their assistance with field experiments at the study site. Thanks also to the Chief Farm Superintendent of BAU for allowing us to produce rice in his field and for helping with rice production.

\section{BGD}

8, 8693-8721, 2011

\section{Seasonality of ecosystem respiration in a double-cropping}

M. S. Hossen et al.

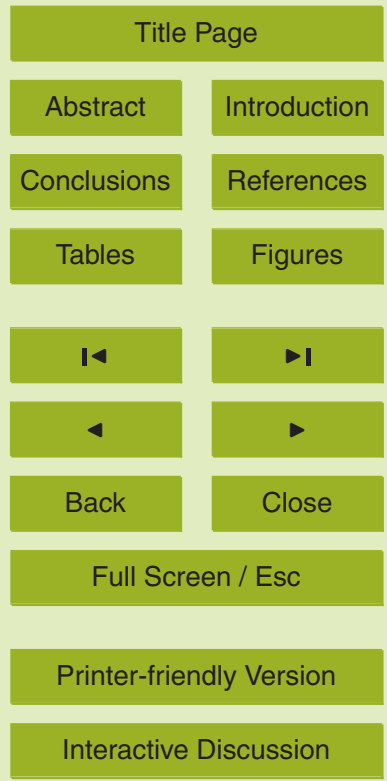




\section{References}

Alberto, M. C. R., Wassmann, R., Hirano, T., Miyata, A., Kumar, A., Padre, A., and Amante, M.: $\mathrm{CO}_{2}$ /heat fluxes in rice fields: Comparative assessment of flooded and non-flooded fields in the Philippines, Agric. For. Meteorol., 149, 1737-1750, 2009.

5 Campbell, C. S., Heilman, J. L., Mclnnes, K. J., Wilson, L. T., Medley, J. C., Wu, G., and Cobos, D. R.: Diel and seasonal variation in $\mathrm{CO}_{2}$ flux of irrigated rice, Agric. For. Meteorol., 108, 15-27, 2001.

Davidson, E. A., Janssens, I. A., and Luo, Y.: On the variability of respiration in terrestrial ecosystems: Moving beyond $Q_{10}$, Glob. Change Biol., 12, 154-164, 2006.

10 Farquhar, G. D., Caemmerer, S. V., and Berry, J. A.: A biochemical model of photosynthetic $\mathrm{CO}_{2}$ assimilation in leaves of C3 species, Planta, 149(1), 78- 90, 1980.

Falge, E., Baldocchi, D., Olson, R., Anthoni, P., Aubinet, M., Berrnhofer, C., Burba, G., Ceulemans, R., Clement, R., Dolman, H., Granier, A., Gross, P., Grünwald, T., Hollinger, D., Jensen, N.-O., Katul, G., Keronen, P., Kowalski, A., Lai, C. T., Law, B. E., Meyers, T., Moncrieff, J., Moors, E., Munger, J. W., Pilegaard, K., Rannik, Ü., Rebmann, C., Suyker, A., Tenhunen, J., Tu, K., Verma, S , Vesala, T., Wilson, K., and Wofsy, S.: Gap filling strategies for defensible annual sums of net ecosystem exchange, Agric. For. Meteorol., 107, 43-69, 2001a.

Falge, E., Baldocchi, D., Olson, R., Anthoni, P., Aubinet, M., Berrnhofer, C., Burba, G., Ceulemans, R., Clement, R., Dolman, H., Granier, A., Gross, P., Grünwald, T., Hollinger, D., Jensen, N.-O., Katul, G., Keronen, P., Kowalski, A., Lai, C. T., Law, B. E., Meyers, T., Moncrieff, J., Moors, E., Munger, J. W., Pilegaard, K., Rannik, Ü., Rebmann, C., Suyker, A., Tenhunen, J., Tu, K., Verma, S , Vesala, T., Wilson, K., and Wofsy, S.: Gap filling strategies for long term energy flux data sets, Agric. For. Meteorol., 107, 71-77, $2001 \mathrm{~b}$.

25 Finkelstein, P. L. and Sims, P. F.: Sampling error in eddy correlation flux measurements, J. Geophys. Res., 106(D4), 3503-3509, 2001.

Gifford, R. M.: Plant respiration in productivity models: Conceptualisation, representation and issues for global terrestrial carbon-cycle research, Funct. Plant Biol., 30(2), 171-186, 2003.

Griffis, T. J., Black, T. A., Gaumont-Guy, D., Drewitt, G. B., Nesic, Z., Barr, A. G., Morgenstern, K., and Kljun, N.: Seasonal variation and partitioning of ecosystem respiration in a southern boreal aspen forest, Agric. For. Meteorol., 125, 207-223, 2004.

Grogan, P. and Chapin, F. S.: Arctic soil respiration: Effects of climate and vegetation depend

\section{Seasonality of ecosystem respiration in a double-cropping}

M. S. Hossen et al.

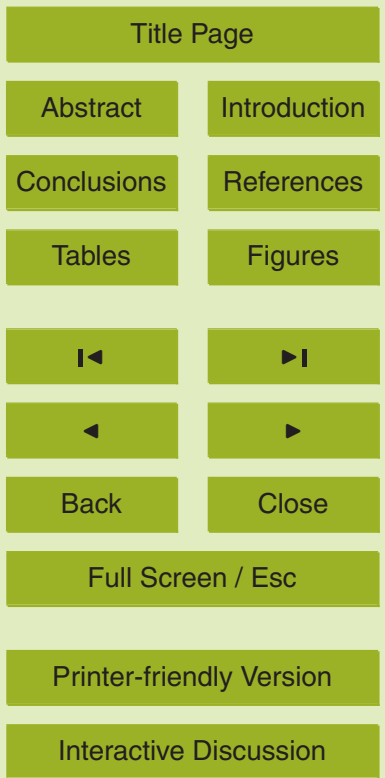


on season, Ecosystems, 2, 451-459, 1999.

Hanson, P. J., Edwards, N. T., Garten, C. T., and Andrews, J. A.: Separating root and soil microbial contributions to soil respiration: A review of methods and observations, Biogeochem., 48, 115-146, 2000.

5 Hossen, M. S., Mano, M., Miyata, A., Baten, A., Hiyama, T.: Surface energy partitioning and evapotranspiration over a double-cropping paddy field in Bangladesh, Hydrol. Process., doi:10.1002/hyp.8232, 2011.

IPCC, Climate Change 2007: Impacts, Adaptation and Vulnerability.Contribution of Working Group II to the Fourth Assessment Report of the Intergovernmental Panel on Climate Change, edited by: Parry, M. L., Canziani, O. F., Palutikof, J. P., van der Linden, P. J., Hanson, C. E., Cambridge University Press, Cambridge, United Kingdom and New York, NY, USA, 2007.

Jassal, R. S., Black, T. A., Novak, M. D., Guay, G., and Nesic, Z.: Effect of soil water stress on soil respiration and its temperature sensitivity in an 18-year-old temperate Douglas-fir stand,

15 Glob. Change Biol., 14, 1305-1318, 2008.

Jin, X., Wang, S., and Zhou, Y.: Microbial $\mathrm{CO}_{2}$ production from surface and subsurface soil as affected by temperature, moisture, and nitrogen fertilization, Aus. J. Soil Res. 46, 273-280, 2008.

Kaimal, J. C. and Finnigan, J. J.: Atmospheric Boundary Layer Flows. Oxford University Press, 289 pp., 1994.

Lei, $H$. and Yang, D.: Seasonal and interannual variations in carbon dioxide exchange over a cropland in the North China Plain, Glob. Change Biol. 16, 2944-2957, 2010.

Lloyd, J. and Taylor, J. A.: On the temperature-dependence of soil respiration, Funct. Ecol., 8(3), 315-323, 1994.

25 Massman, W. J.: A simple method for estimating frequency response corrections for eddy covariance system, Agric. For. Meteorol., 104, 185-198, 2000.

Miyata, A., Leuning, R., Denmead, O. T., Kim, J., and Harazono, Y.: Carbon dioxide and methane fluxes from an intermittently flooded paddy field, Agric. Forest Meteorol., 102(4), 287-303, 2000.

30 Qi, Y. and $\mathrm{Xu}, \mathrm{M}$.: Separating the effects of moisture and temperature on soil $\mathrm{CO}_{2}$ efflux in a coniferous forest in the Sierra Nevada Mountains, Plant Soil, 237(1), 15-23, 2001.

Rahman, A., Ali, M. A., and Chowdhury, F.: People's Report on Bangladesh Environment 2001, 11, 37 pp., 2001.

\section{BGD}

8, 8693-8721, 2011

\section{Seasonality of ecosystem respiration in a double-cropping}

M. S. Hossen et al.

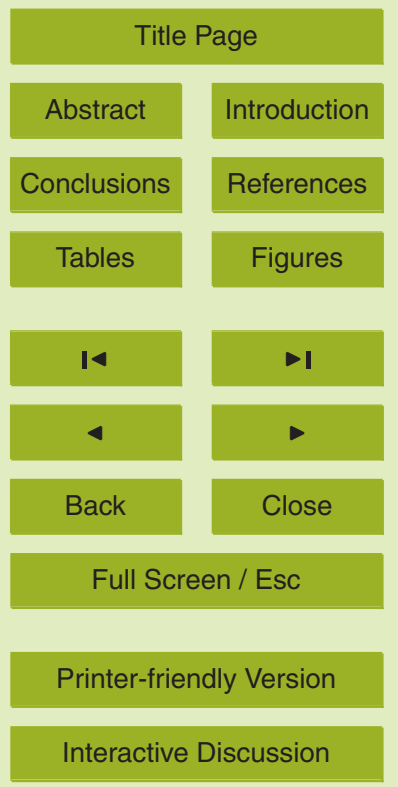


Raich, J. W. and Tufekcioglu, A.: Vegetation and soil respiration: Correlations and controls, Biogeochem., 48, 71-90, 2000.

Raich, J. W., Potter, C. S., Bhagawati, D.: Interannual variability in global soil respiration, 198094, Glob. Change Biol., 8, 800-812, 2002.

5 Reichstein, M., Falge, E., Baldocchi, D., Papale, D., Aubinet, M., Berbigier, P., Bernhofer, C., Buchmann, N., Gilmanov, T., Granier, A., Grunwald, T., Havrankova, K., Ilvesniemi, H., Janous, D., Knohl, A., Laurila, T., Lohila, A., Loustau, D., Matteucci, G., Meyers, T., Miglietta, F., Ourcival, J. M., Pumpanen, J., Rambal, S., Rotenberg, E., Sanz, M., Tenhunen, J., Seufert, G., Vaccari, F., Vesala, T., Yakir, D., and Valentini, R.: On the separation of net ecosystem exchange into assimilation and ecosystem respiration: review and improved algorithm, Glob. Change Biol., 11, 1424-1439, 2005.

Reicosky, D. C. and Lindstrom, M. J.: Fall tillage method: effect on short-term carbon dioxide flux from soil, Agron. J., 85, 1237-1243, 1993.

Saito, M., Miyata, A., Nagai, H., and Yamada, T.: Seasonal variation of carbondioxide exchange 15 in rice paddy field in Japan, Agric. For. Meteorol., 135, 93-109, 2005.

Saleska, S., Miller, S. D., Matross, D. M., Goulden, M. L., Wofsy, S. C., da Rocha, H. R., de Camargo, P. B., Crill, P., Daube, B. C., de Freitas, H. C., Hutyra, L., Keller, M., Kirchoff, V., Menton, M., Munger, J. W., Hammond Pyle, E., Rice, A. H., and Silva, H.: Carbon in Amazon forests: unexpected seasonal fluxes and distrubance-induced losses, Science, 302, 15541557, 2003.

Schimel, D. S.: Terrestrial ecosystems and the carbon cycle, Glob. Change Biol., 1, 77-91, 1995.

Schlesinger, W. H.: Biogeochemistry: An analysis of global change, Academic Press, San Diego, CA., 1991.

Tanner, C. B. and Thurtell, G. W.: Anemoclinometer Measurements of Reynolds Stress and Heat Transport in the Atmospheric Surface Layer, University of Wisconsin Tech. Rep., ECOM-66-G22-F, 82 pp., 1969.

Twine, T. E., Kustas, W. P., Norman, J. M., Cook, D. R., Houser, P. R., Meyers, T. P., Prueger, J. H., Starks, P. J., and Wesely, M. L.: Correcting Eddy-covariance flux underestimates over a 30 grassland, Agric. For. Meteorol., 103, 279-300, 2000.

UNDP (United Nations Development Program) and FAO (Food and Agriculture Organization): Land Resources Appraisal of Bangladesh for Agricultural Development, Report 2, Agroecological Regions of Bangladesh, UNDP, FAO, Rome, 116 pp., 1998.

\section{BGD}

8, 8693-8721, 2011

\section{Seasonality of ecosystem respiration in a double-cropping}

M. S. Hossen et al.

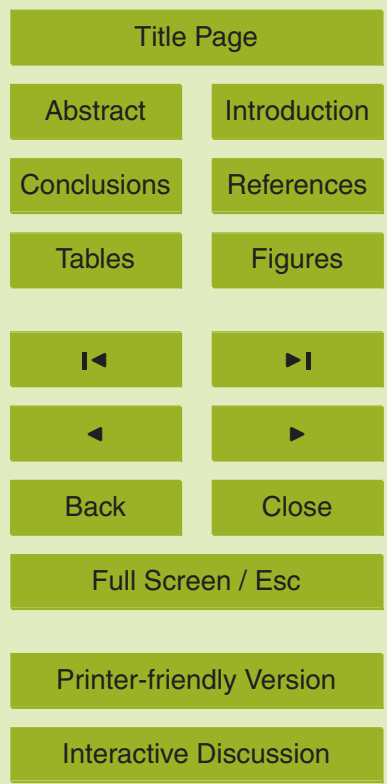


Valentini, R., Matteucchi, G., Dolman, H., Schulze, E. D., Rebmann, C., Moors, E. J., Granier, A., Gross, P., Jensen, N. O., Pilgaard, K., Lindroth, A., Grelle, A., Bernhofer, C., Gronwald, T., Aubinet, M., Ceulemans, R., Kowalski, A. S., Vesala, T., Rannik, T., Berbigier, P., Lousteau, D., Gudmundsson, J., Thorgairsson, H., Ibrom, A., Morgenstern, K., Clement, R., Moncrieff, J., Montagnani, L., Minerbi, S., and Jarvis, P. G.: Respiration as the main determinant of carbon balance in European forests, Nature, 404, 861-865, 2000.

Vickers, D. and Mahrt, L.:. Quality control and flux sampling problems for tower and aircraft data, J. Atmos. Oceanic Technol., 14, 512-526, 1997.

Webb, E. K., Pearman, G. I., and Leuning, R.: Correction of flux measurements for density effects due to heat and water vapor transfer, Quat. J. R. Meteorol. Soc., 106, 85-100, 1980.

Wilson, K., Goldstein, A., Falge, E., Aubinet, M., Baldocchi, D., Berbigier, P., Bernhofer, C., Ceulenmans, R., Dolman, H., Field, C., Grelle, A., Ibrom, A., Law, B. E., Kowalski, A., Meyers, T., Moncrieff, J., Monson, R., Oechel, W., Tenhunen, J., Valentini, R., and Verma, S.: Energy balance closure at FLUXNET sites, Agric. For. Meteorol., 113, 223-243, 2002.

Yatagai, A., Arakawa, O., Kamiguchi, K., Kawamoto, H., Nodzu, M. I., and Hamada, A.: A 44year daily gridded precipitation dataset for Asia based on a dense network of rain gauges, SOLA, 5, 137-140, 2009.

Zhou, X., Wan, S., and Lou, Y.: Source components and interannual variability of soil $\mathrm{CO}_{2}$ efflux under experimental warming and clipping in a grassland ecosystem, Glob. Change Biol., 13,
BGD

8, 8693-8721, 2011

Seasonality of ecosystem respiration in a double-cropping

M. S. Hossen et al.

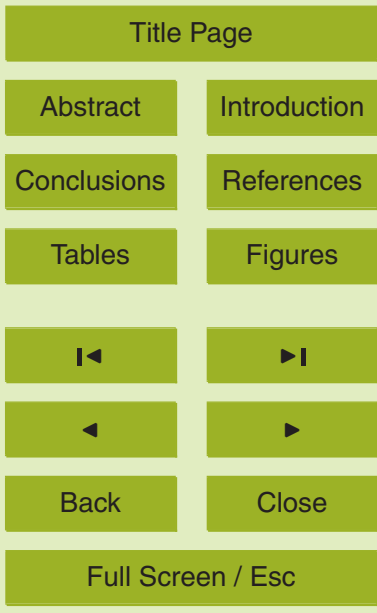

Printer-friendly Version

Interactive Discussion 
BGD

8, 8693-8721, 2011

\section{Seasonality of ecosystem respiration in a double-cropping}

Table 1. Cultivation and field management practices for Boro and Aman rice.

\begin{tabular}{lll}
\hline Event & Boro season (2007) & Aman season (2007) \\
\hline Variety & BRRI dhan 29 & BRRI dhan 30 \\
Final plowing & DOY 25 & DOY 230 \\
Fertilizer application as a basal dose & DOY 25 & DOY 230 \\
Fertilizer application $(\mathrm{kg} / \mathrm{ha})^{*}$ & Urea:TSP:MOP:Gypsum:ZnSO ${ }_{4}$ 110:90:90:75:10 & Urea:TSP:MOP:Gypsum 185:50:37:37 \\
Seedling age & 63 days & 64 days \\
Transplanting & DOY 29 & DOY 232 \\
Spacing & $25 \mathrm{~cm} \times 15 \mathrm{~cm}$ & $20 \mathrm{~cm} \times 15 \mathrm{~cm}$ \\
Total drainage period & 32 days & 27 days \\
Harvest & DOY 146 & DOY 336 \\
\hline
\end{tabular}

${ }^{*}$ All fertilizers were applied as a basal dose during final land preparation, except urea. Urea was applied in three installments: one third at each the basal dose, seedling stage, and tillering stage.

M. S. Hossen et al.

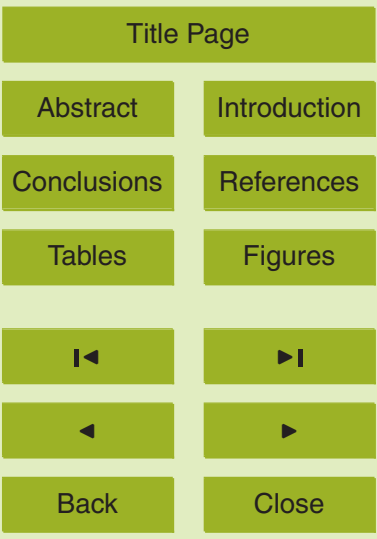

Full Screen / Esc

Printer-friendly Version

Interactive Discussion 
BGD

8, 8693-8721, 2011

Seasonality of ecosystem respiration in a double-cropping

Table 2. Seasonal and annual ecosystem respiration (RE) and gross primary production (GPP) in a double-rice cropping field.

\begin{tabular}{lccccc}
\hline Period & $\begin{array}{c}\text { Sum of RE } \\
\left(\mathrm{g} \mathrm{C} \mathrm{m}^{-2}\right)\end{array}$ & $\begin{array}{c}\text { Average RE } \\
\left(\mathrm{g} \mathrm{C} \mathrm{m}^{-2} \mathrm{~d}^{-1}\right)\end{array}$ & $\begin{array}{c}\text { Sum of GPP } \\
\left(\mathrm{g} \mathrm{C} \mathrm{m}^{-2}\right)\end{array}$ & $\begin{array}{c}\text { Average GPP } \\
\left(\mathrm{g} \mathrm{C} \mathrm{m}^{-2} \mathrm{~d}^{-1}\right)\end{array}$ & RE/GPP \\
\hline Boro & 412 & 3.76 & 711 & 6.52 & 0.58 \\
Summer fallow & 257 & 2.89 & 235 & 2.62 & 1.09 \\
Aman & 311 & 3.08 & 601 & 5.95 & 0.52 \\
Winter fallow & 68 & 1.09 & 28 & 0.44 & 2.46 \\
Annual & 1047 & 2.86 & 1574 & 4.31 & 0.67 \\
\hline
\end{tabular}

M. S. Hossen et al.

\section{Title Page}

Abstract

Introduction

Conclusions

References

Tables

Figures

14

Back

Close

Full Screen / Esc

Printer-friendly Version

Interactive Discussion 
BGD

8, 8693-8721, 2011

\section{Seasonality of ecosystem} respiration in a double-cropping

M. S. Hossen et al.

Table 3. Fitted relationship of ecosystem respiration with environmental factors.

\begin{tabular}{lccccc}
\hline Period & \multicolumn{2}{c}{ Fitting parameters } & \multicolumn{2}{c}{$R^{2}$} \\
& $b_{1}$ & $b_{2}$ & $a$ & $c$ & \\
\hline Boro & 0.041 & 0.101 & 0.091 & 2.671 & 0.87 \\
Aman & 0.041 & 0.102 & 0.091 & 1.679 & 0.62 \\
\hline
\end{tabular}

Title Page

Abstract

Introduction

Conclusions

References

Tables

Figures

14

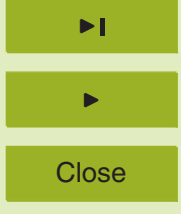

Back

Full Screen / Esc

Printer-friendly Version

Interactive Discussion 


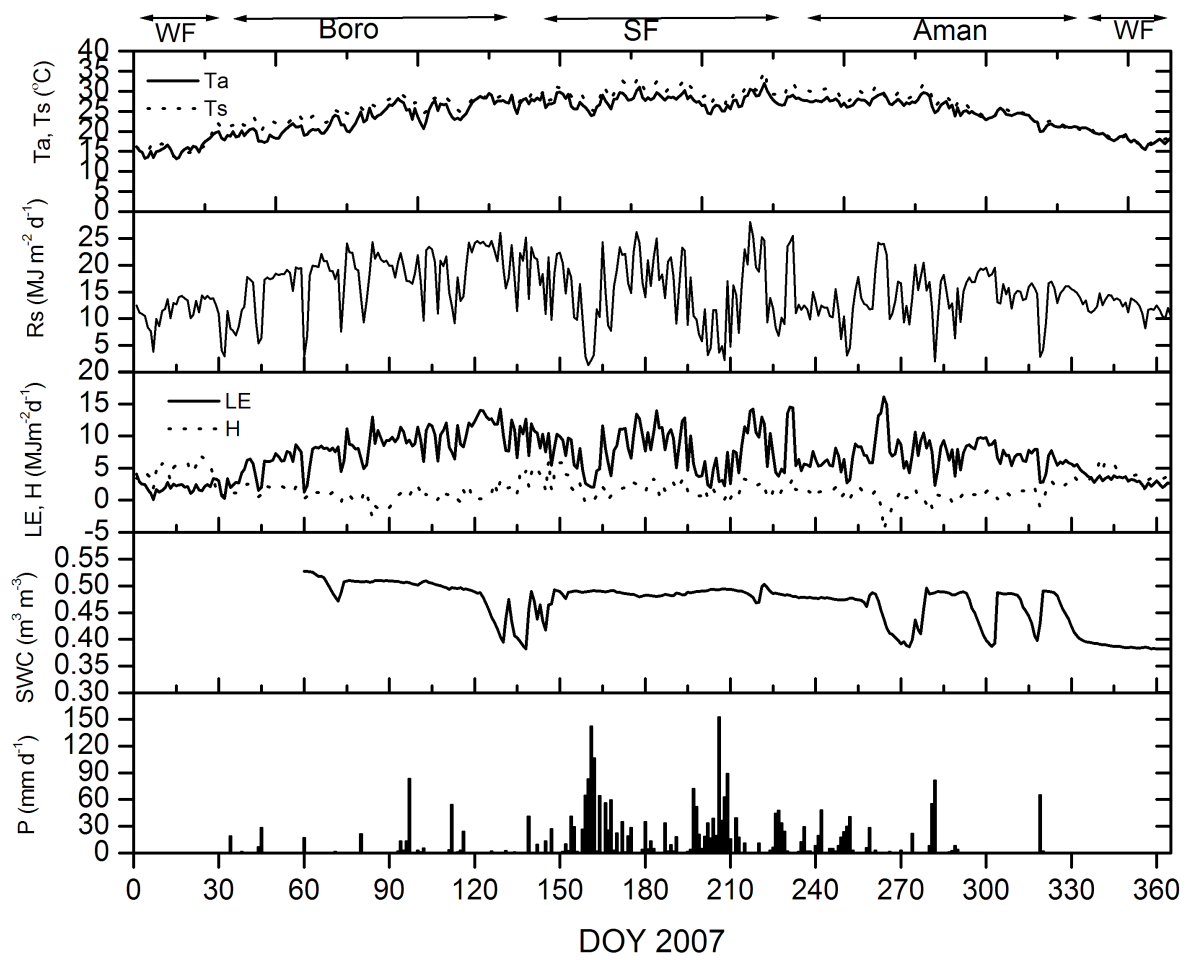

Fig. 1. Seasonal courses of meteorological variables at a rice paddy field in Mymensingh, Bangladesh, in 2007. Ta: daily mean air temperature at $2.95 \mathrm{~m}$, Ts: daily mean soil temperature at $4.5 \mathrm{~cm}$ depth, Rs: daily sum of solar radiation, LE: daily sum of latent heat flux at $2.95 \mathrm{~m}$, $\mathrm{H}$ : daily sum of sensible heat flux at $2.95 \mathrm{~m}$, SWC: daily mean soil water content at $0-10 \mathrm{~cm}$ depth, and P: daily precipitation. WF and SF indicated winter fallow and summer fallow.
BGD

8, 8693-8721, 2011

\section{Seasonality of ecosystem respiration in a double-cropping}

M. S. Hossen et al.

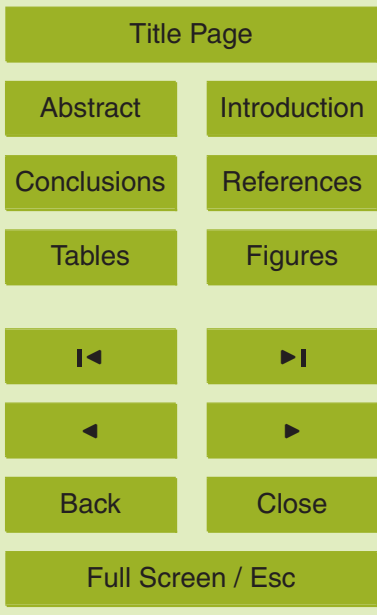

Printer-friendly Version

Interactive Discussion 


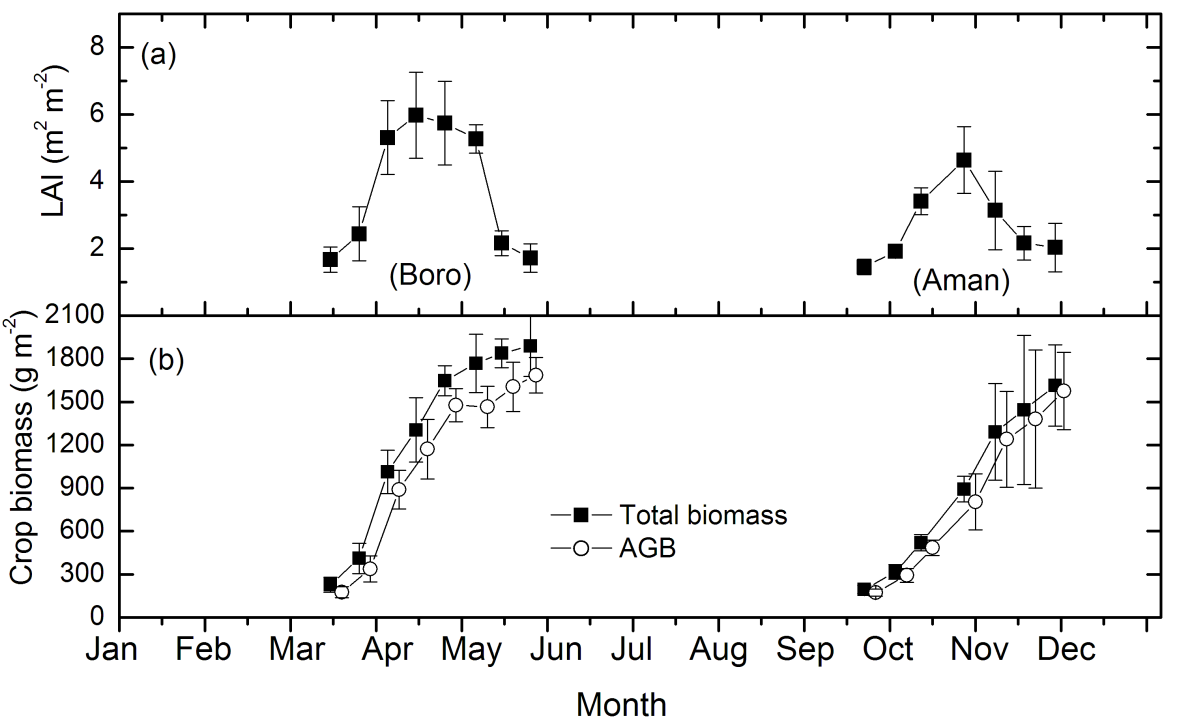

Fig. 2. Seasonal changes in (a) leaf area index (LAI) and (b) crop biomass in the doublecropping rice field in Mymensingh, Bangladesh. ABG: Above ground biomass.
BGD

8, 8693-8721, 2011

\section{Seasonality of ecosystem respiration in a double-cropping}

M. S. Hossen et al.

\section{Title Page}

\section{Abstract}

Introduction

Conclusions

References

Tables

Figures

14

- I

4

Back

Close

\section{Full Screen / Esc}

Printer-friendly Version 
BGD

8, 8693-8721, 2011

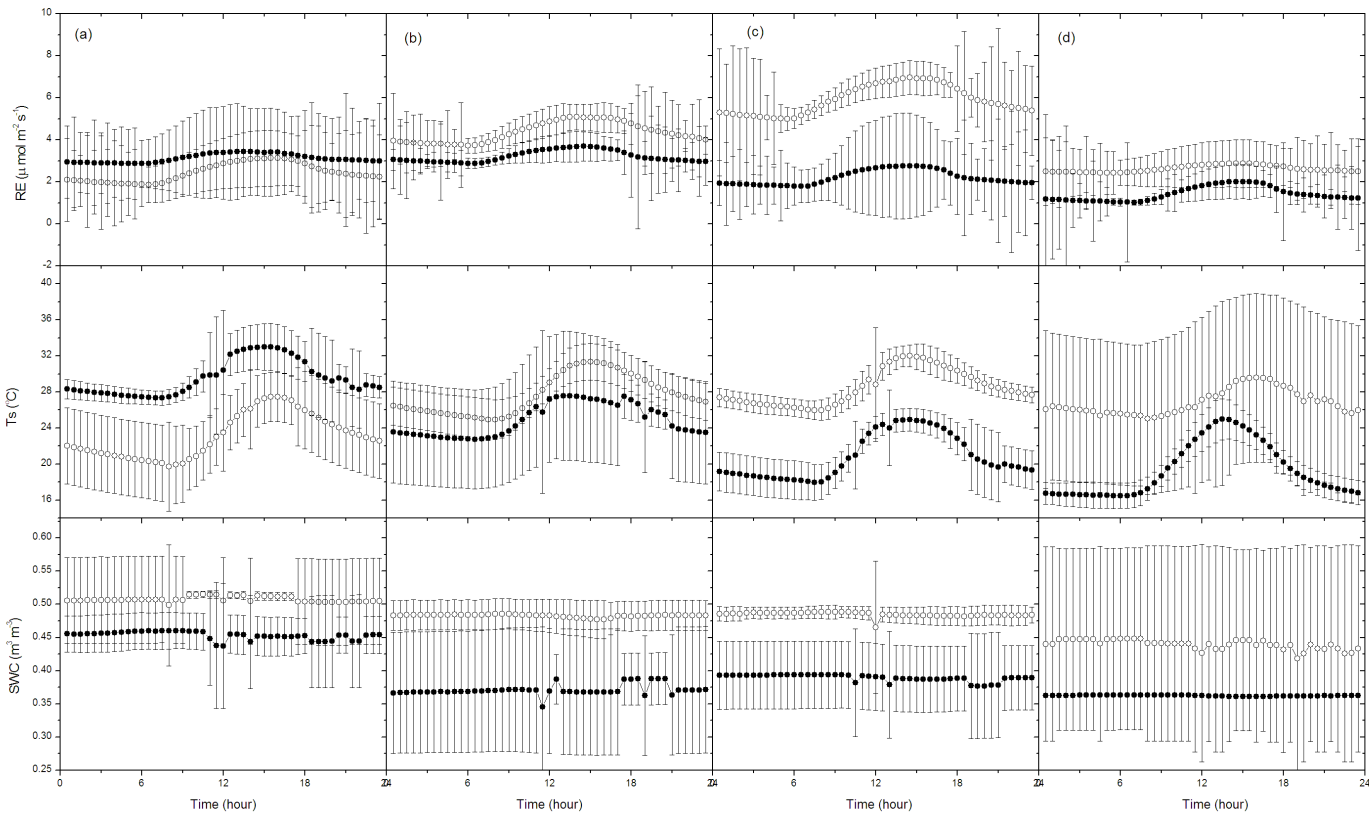

Fig. 3. Diurnal variations in ecosystem respiration (RE), soil temperature (Ts) at $4.5 \mathrm{~cm}$ depth, and soil water content (SWC) at $0-10 \mathrm{~cm}$ depth for different phenological stages: (a) vegetative, (b) reproductive, (c) mature and harvest, and (d) the subsequent fallow period. Open circles represent the Boro season, and closed circles represent the Aman season. The values were averaged over the growth stages, and bars indicate the standard deviation.

\section{Seasonality of ecosystem respiration in a double-cropping}

M. S. Hossen et al.

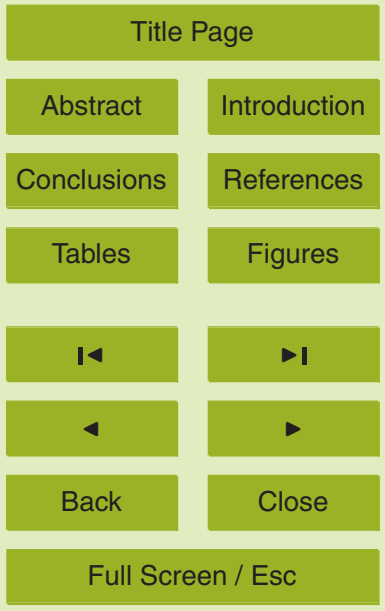

Printer-friendly Version

Interactive Discussion 


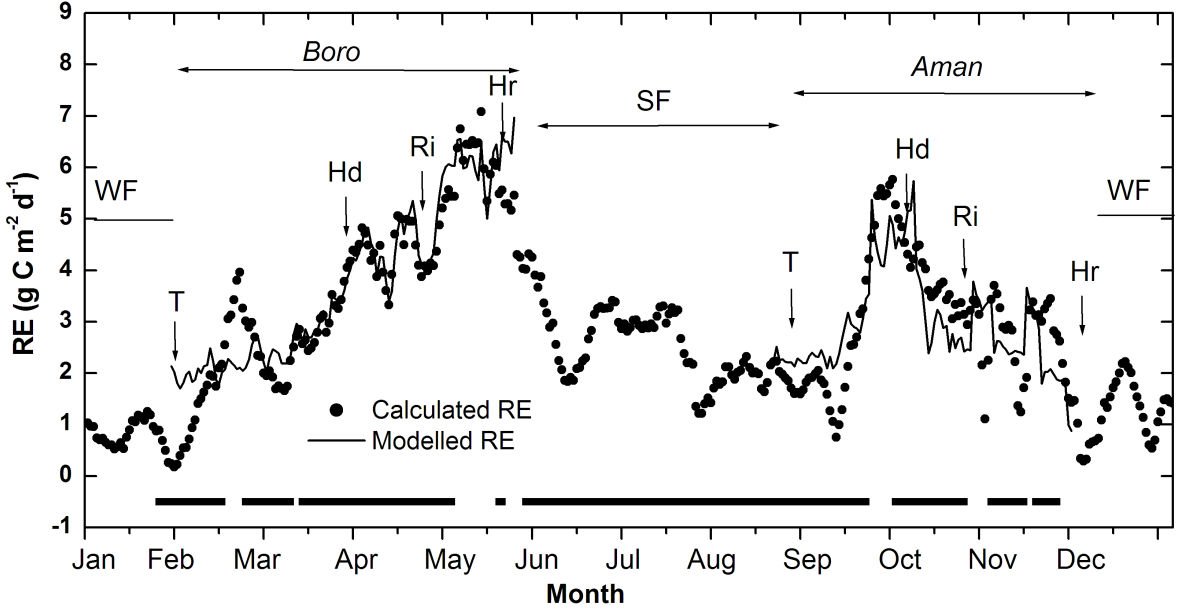

Fig. 4. Seasonal variation in daily ecosystem respiration (RE) at the Mymensingh site in 2007. $\mathrm{T}$ : transplanting, $\mathrm{Hd}$ : heading, Ri: ripening, and $\mathrm{Hr}$ : harvest date. Horizontal black line indicates a flooded period. WF and SF is same as in Fig. 1.
BGD

8, 8693-8721, 2011

\section{Seasonality of ecosystem} respiration in a double-cropping

M. S. Hossen et al.

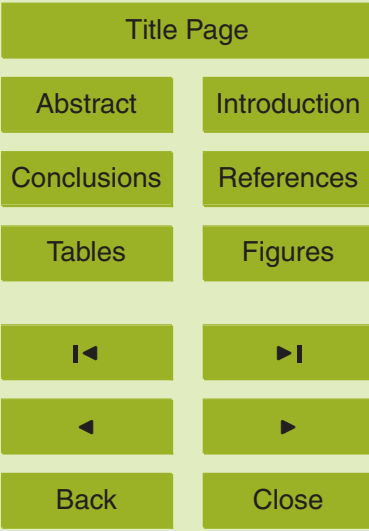

Full Screen / Esc

Printer-friendly Version

Interactive Discussion 
BGD

8, 8693-8721, 2011

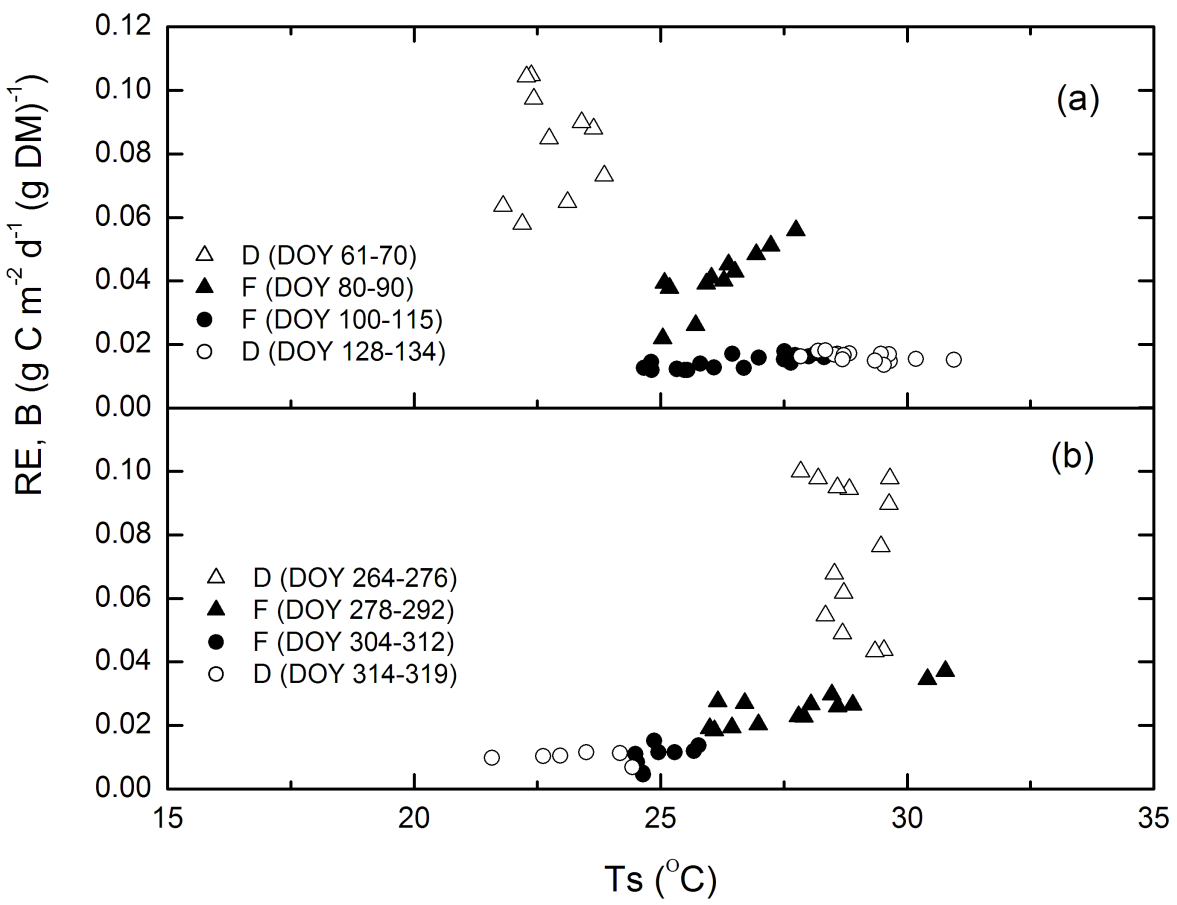

\section{Seasonality of ecosystem respiration in a double-cropping}

M. S. Hossen et al.

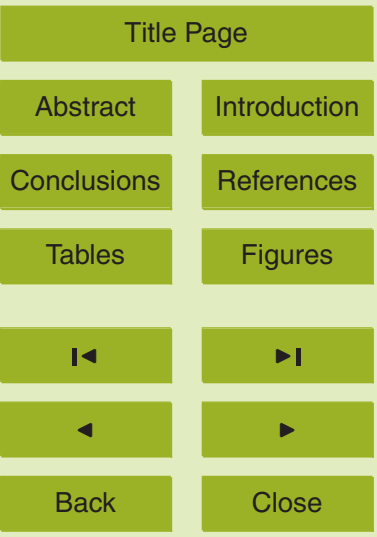

Fig. 5. Relationships between the daily mean soil temperature (Ts) and daily ecosystem respiration per unit aboveground biomass (RE, B) in the flooded and drained periods for the (a) Boro and (b) Aman seasons. F and D indicate flooded and drained conditions, respectively.

\section{Full Screen / Esc}

Printer-friendly Version

Interactive Discussion 
BGD

8, 8693-8721, 2011

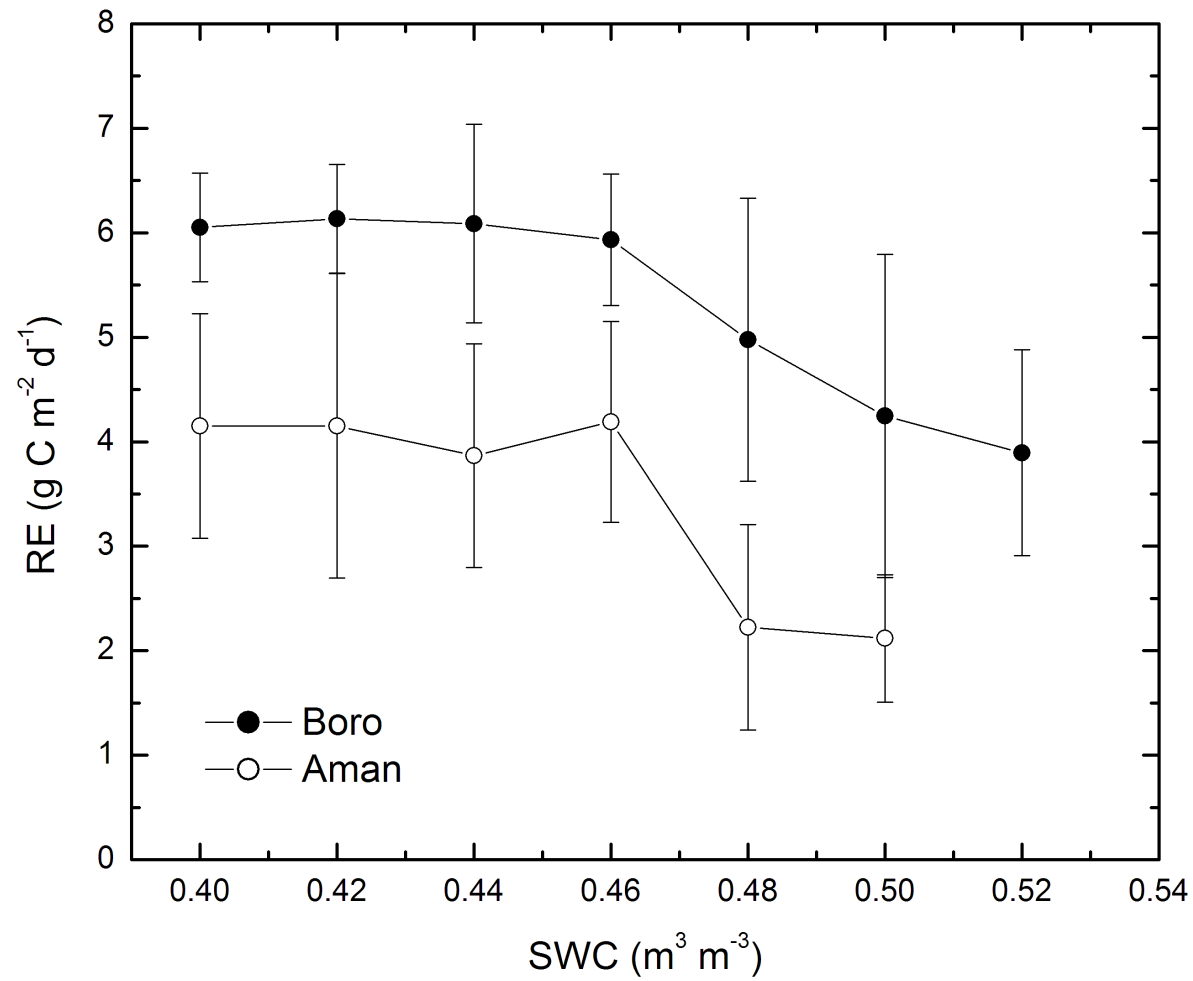

\section{Seasonality of ecosystem respiration in a double-cropping}

M. S. Hossen et al.

\section{Title Page}

\section{Abstract}

Introduction

Conclusions

References

Tables

Figures

14

$>1$

4

Back

Close

Full Screen / Esc

Fig. 6. Relationship between ecosystem respiration (RE) and soil water content (SWC).

Printer-friendly Version

Interactive Discussion 
BGD

8, 8693-8721, 2011

\section{Seasonality of ecosystem \\ respiration in a double-cropping}
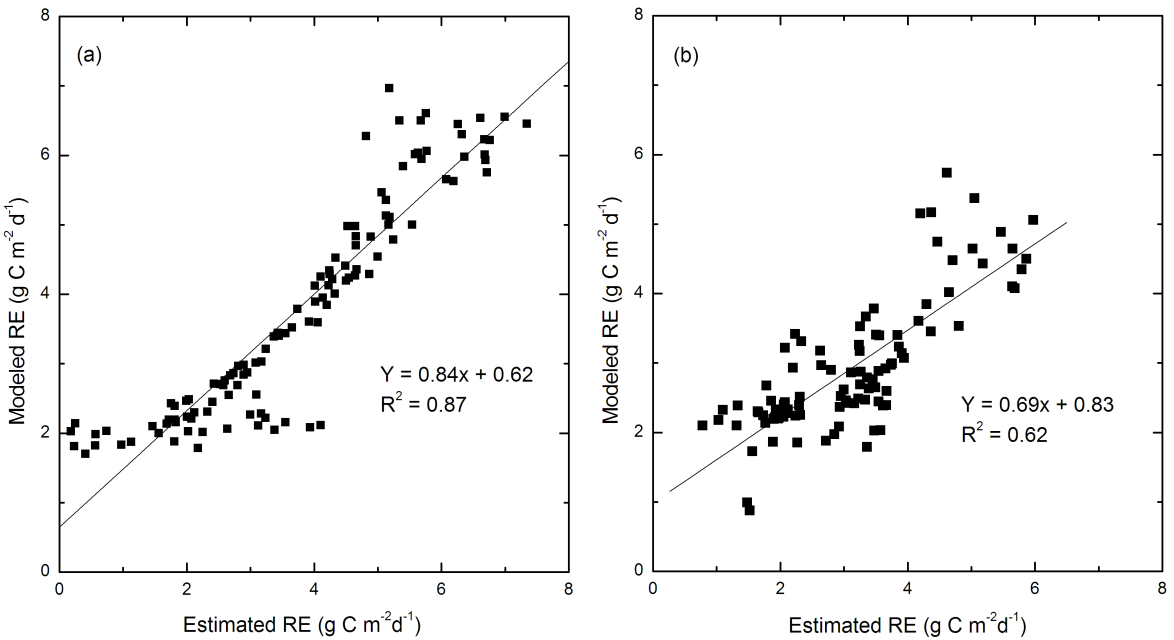

M. S. Hossen et al.

\section{Title Page}

Abstract

Introduction

Conclusions

References

Tables

Figures

14

$>$ I

$<$

Back

Close

Full Screen / Esc

Printer-friendly Version

Interactive Discussion 